\title{
Economic Impact of Mutant Cassava (Manihot Species) for Agricultural Improvement in Ghana
}

\author{
Kwamina Ewur Banson ${ }^{1}$, Harry Amoatey ${ }^{1}$ and Joe Frederick Cobbinah ${ }^{2}$ \\ 1. Department of Technology Transfer Centre (TTC), Biotechnology and Nuclear Agriculture Research Institute (BNARI), Ghana \\ Atomic Energy Commission (GAEC), Legon-Accra, Ghana \\ 2. Department of Engineering, Takoradi Polytechnic, Takoradi, Ghana
}

Received: March 4, 2014 / Published: April 20, 2014.

\begin{abstract}
The importance of agricultural innovations for raising the living standards of farmers has received substantial attention from the economic and political communities. In Ghana, cassava serves as an important source of calorie and cash crop. Production constraints such as the cassava mosaic disease caused by virus have limit farmers access to productivity potentials and marketing. Breeding efforts attempting to address this constraints have had some success such as the mutant Tech Bankye virus resistant variety. This research, therefore, analysed the impact of some production input on mutant cassava productivity growth in Ghana with the use of Cobb-Douglas production function. Results show that farmers cultivate the mutant variety in addition to other traditional varieties to averse risking in marketing and income. The average cost of production of the mutant variety is higher compared to that of the traditional variety. Eighty percent of the farmers complained difficulty in accessing market for the mutant variety because it could not replace the traditional variety in terms of its texture for the local native "fufu" production and "ampesi" and also deteriorate quickly in storage. However, for industrial production of "gari" and starch, the mutant is the best. Both the mutant cassava and the traditional varieties showed increasing returns to scale, however, the returns to scale of the mutant variety were lower compared to that of the traditional variety. Also, the opportunity cost of forgoing the traditional varieties to cultivating the mutant variety was very high making adopted farmers hesitant to continue it cultivation.
\end{abstract}

Key words: Technology adoption, market, production cost, production function, mutant variety, opportunity cost, returns to scale, agricultural productivity.

\section{Introduction}

Increasing innovations and export of agricultural products in a sustainable manner can be an effective way of reducing poverty and enhancing economic growth in developing countries [1]. Cassava (Manihot esculenta Crantz), a root tuber crop, is widely grown in Ghana as staple and export crop, respectively [2-4]. However, production constraints such as the cassava mosaic virus (CMV) [5] negatively impact on its economic importance to the Ghanaian economy [6, 7]. Cassava is cultivated mainly by both resource rich and poor farmers, often on marginal lands [8]. For them,

\footnotetext{
Corresponding author: Kwamina Ewur Banson, M.Sc., research field: agricultural economics. E-mail: asskeroo@yahoo.com; kwamina.banson@adelaide.edu.au.
}

the crop is vital for both food security and income generation. Cassava production in Ghana is increasing because the crop is drought resistant and adapts well to relatively poor soils where other crops fail to do well. Cassava is incorporated into most native diets by households and the demands for cassava and cassava products are on the increase not only at domestic, but also at industrial levels. It also serves as livestock feed [9]. In Ghana, it serves as the second most important source of calories, an inexpensive and essential food for families having little or no money, and an emerging cash crop [10]. Cassava is vulnerable to a broad range of virus's diseases among which the CMV being the most severe and widespread, limiting it productivity [11]. CMV produces a variety of foliar 
symptoms that include mosaic, mottling, misshapen and twisted leaflets, and an overall reduction in yield. It is transmitted by infectious mealy bugs and infected bud wood and it is also one of the most devastating plagues of cocoa that threatened to wipe out the cocoa industry in the 1940s since its discovery in 1936 in Ghana [12, 13]. The cocoa swollen shoot virus also causes defoliation, dieback of the plant and severe yield losses.

Farmers' successes in marketing their cassava and cocoa have fallen well short of its potential due to these virus diseases which are incurable [14, 15].

The government has devoted much attention to combat these diseases since 1946 after it was discovered that the disease is incurable [12]. Initially, eradication campaigns including innovations such as the introduction of block plantings in the 1950s [12, 16], where large areas lands were cleared and replanted in contiguous blocks; secondly, chemical pesticides and, to a limited extent, integrated pest management (IPM) applied to control the mealy bud in Ghana failed [17, 18]; thirdly, the "plant-as-you-cut" scheme introduced in the 1970s, under which the government cut, replanted and maintained the farms for some time before handover them to their owners [12, 19], and finally the "Suhum rehabilitation project” funded by the World Bank [12, 16], where the World Bank sponsored the cutting out of diseased farms and replanting them in blocks with fast growing and early cultivars.

Production constraints, caused by these virus, lead to the breeding and use of mutant varieties [20]. Artificially induced mutations in cultivated plants are one of the tools used by plant breeders to produce resistant plant varieties against diseases and pest. Relative to the conventional breeding methods such as cross-breeding, mutation breeding makes use of possibilities of altering genes by exposing seeds to chemical or ionizing radition to generate resistance varieties for their economic importance [21]. In many cases, according to Ahloowalia et al. [22], the changed traits had a synergistic effect on the cultivation of the crop, agronomic inputs, crop rotation and utilization. For example, the short height genotypes in rice, wheat, barley and maize have contributed significantly to increasing grain yield because of their resistance to lodging and high planting density [22].

Mutation breeding attempting to address the constraints to Ghana cassava and cocoa productivity has had some success such as the Tech Bankye, and Cocoa Swollen Shoot Virus resistant mutant variety [23].

Therefore, this research will use a methodological framework to assess the economic impact of mutant cassava adoption in Ghana to identify reliable information on their actual or likely economic impact is which is lacking.

In view of the importance of agricultural technology for raising the standard of living, it is not surprising that agricultural productivity growth and innovation analyses receive substantial attention from the economic and political communities of developing countries. Over two decades of applications of induced mutation techniques toward crop improvement in Ghana have led to the production of improved mutant varieties especially in two crops, cassava and cocoa. Economic considerations are an important factor in government decision-making on the introduction of genetically modified products in terms of formulating policies and providing research and development (R\&D) in the research arena. Also, the public do not seem to see the economic impact other than the negative aspects of mutation breeding. Reliable information on their actual or likely economic impact is lacking.

Although one can easily see some advantages for the producers (reduction in production costs, increase in productivity), the groups against these products are posing other questions, especially in terms of impacts at the consumer level or in the environmental area. 
Since conventional breeding efforts attempting to address many of the constraints to cassava and cocoa productivity have had some success, the impact will be analysed in actual terms that is an "ex post" evaluation. Therefore, this research analysed the impact of some production variables or inputs on mutant cassava productivity growth and output in Ghana with the use of Cobb-Douglas production function in actual terms based on the most advanced results of the survey research and on studies developed in others institutions, especially where they are already in use by the producers. The data used in this study were regional level agricultural output and inputs for estimating the Cobb-Douglas production function of mutant and traditional cassava varieties' total value from 2008-2013.

\section{Materials and Methods}

The study started with a detail literature review on theoretical approaches, on the concept of mutation breeding, their adoption and impact on economic development. Furthermore, literatures on the Ghanaian agricultural sector were analysed. Both primary and secondary methods were used for data collection. The field survey will take place from July to September 2008 and December 2013 using standardised questionnaires. The samples include 88 farmers who cultivate the mutant (Tech Bankye) and other cassava varieties. Communal leaders of farmer groups and representatives of district governments were also interviewed with unstructured questionnaires. This helped to gain insight into the policies that influence the performance of the agricultural industry in Ghana. Since the total number of mutant cassava growers is not available for the design of a probability sample, their selection was based on snowball sampling in which interviewed farmers were requested to name other farmers making it easier to collect both data on mutant and other cassava varieties for comparative analyses.

\subsection{Economic Impact Evaluation}

Economic impact evaluation tool used in this study is the "Cobb-Douglas production function model", adopted from Zaman and Goschin [24]. The Cobb-Douglas functional form of production functions was used to represent the relationship of an output to inputs. It was proposed by Knut Wicksell, and tested against statistical evidence by Charles Cobb and Paul Douglas in 1928 [24].

The Cobb-Douglas equation was used to analyse the impact of some production variables on agricultural productivity growth.

Production function in general form can be written as:

$$
Y=F\left(X_{i}\right)
$$

where, $Y$ is production output and $X_{i}$ are measured physical production factor inputs. Eq. (1) of production function in log form is:

$$
\begin{gathered}
\log _{e}(Y)=\beta_{0}+\beta_{1} \log _{e} X_{1}+\beta_{2} \log _{e} X_{2} \log _{e}(Y) \\
+\beta_{3} \log _{e} X_{3 \ldots} \beta_{n} \log _{e} X_{n}+\varepsilon \\
\log _{e}(Y)=\beta_{0}+\sum_{i}^{n}\left(\beta_{1} \log _{e} X_{i}\right)
\end{gathered}
$$

where, $X_{i}$ denotes production factors and $\varepsilon$ is the residual of the regression. In our analysis, the agricultural production function (Cobb-Douglas) is specified as follows:

$$
\begin{aligned}
& \log _{e}(V O M)=\beta_{0}+\beta_{1} \log _{e}(L) \\
& +\beta_{2} \log _{e}(K)+\beta_{3} \log _{e}(A)+\varepsilon
\end{aligned}
$$

where, VOM is the value of mutant cassava variety; $L$ is agricultural labour force; $K$ is capital input; $A$ is acreage of agricultural land cultivated; the coefficients $\beta_{i}(i=1,2,3)$ are the elasticity of the respective variables with respect to agricultural production, with the assumption that $i>0$.

To evaluate the economic impact of the agricultural research, the concept of economic surplus is the most used method to analyse the economic impact generated by the agricultural research [25]. In this approach, the coefficients of inputs-elasticities of labour, capital and land of the production values are used. The supply curve would be located to the 
left-hand side if there were no technological innovation generated by agricultural research (Fig. 1).

When technological innovation occurs, the consumers benefit with increased in the supply of products and producers benefit with a decreasing in production costs. In order to calculate this surplus, it is necessary to know the rate of supply shift due to the new technology. This rate is calculated by comparing the traditional technology to the new technology (e.g., traditional variety vs. improved variety). This rate of shift as a result of agricultural research is computed, in general, using yield increases due to new varieties compared with the traditional varieties and the rate of adoption of new varieties is estimated as percentage of the cultivated area.

\subsection{The Study Area}

The study areas were selected purposefully in the Ashanti region of Ghana; Ejisu-Juaben Municipal District and Tafo where bulks of the mutant varieties were cultivated. Thus, the study was conducted around the peri-urban region of Kumasi region. The bulk of the nation's cassava is produced in the South and middle of Ghana, which accounts for roughly $78 \%$ of the total cassava production in Ghana. In the Northern region of Ghana, only $2 \%$ is devoted to cassava production. But the production and area under cultivation in Northern Ghana is increasing due to the fact that cassava also grows on marginal land and yields a sufficient amount for the semi-subsistence farmers, who often lack cash for fertiliser or other costly inputs for crop production. Additional informations were obtained from Root and Tuber Improvement and Marketing Programme (RTIMP) of Ghana on cultivation of mutant varieties.

Cassava propagation is done asexually. Cassava farmers' uses purchased or own stems from parts of the mother plant of previous cultivations. The first harvest of fruits takes place after eight months to 10 months. One of the main aspects of cassava production is ground preparation, for which suitable machinery is required. Ground preparative work must be efficient to assure good drainage and penetration of the roots. Land preparation is done mechanically (large producers) or manually (small scale producers). Weeding is critical and mostly done manually. Most commercial producers prepare their land mechanically and mostly control weeds with herbicide. The plants are usually fertilized with urea, potassium sulphate, triple super phosphate fertilizer depending on soil fertility and the variety. Farmers also use a lot of chemicals to control diseases and pests.

\section{Results and Discussion}

The Cobb-Douglas equation was used to analyse the economic impact of mutant cassava and other traditional cassava varieties on agricultural productivity growth in Ghana. Exploring agricultural potential is a key for agricultural growth. Land expansion, which is the dominant source of recent

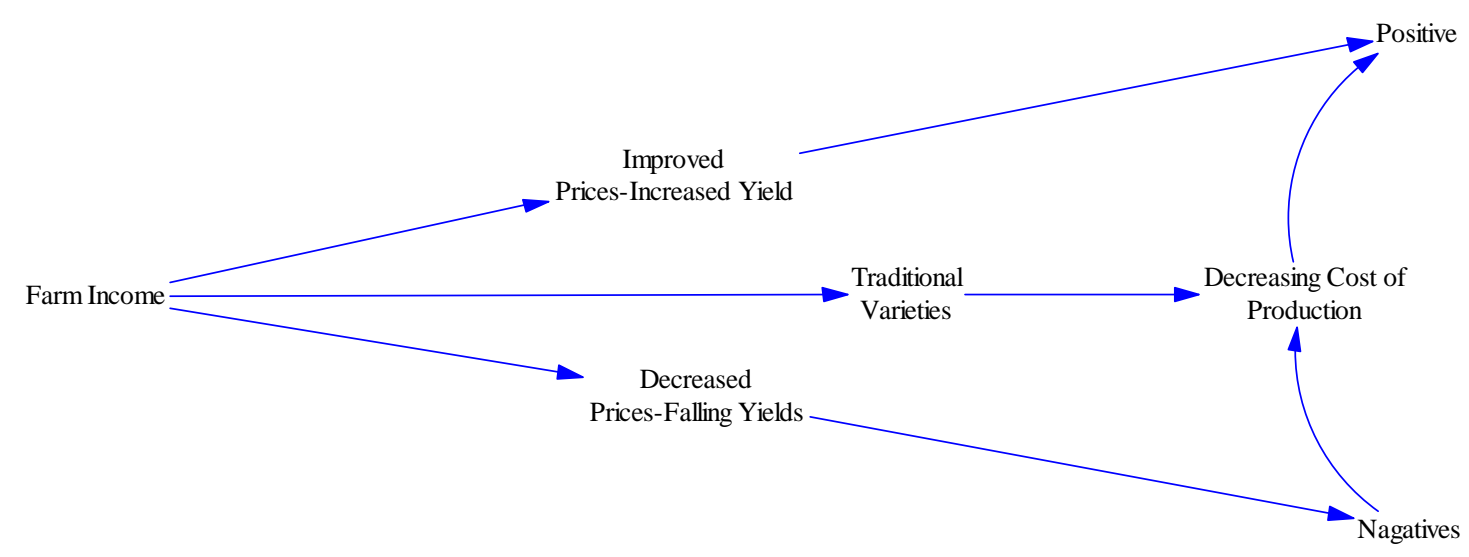

Fig. 1 Technological innovation generated by agricultural research. 
growth, should not be seen as a main engine of further agricultural growth [26]. Continuous expansion of land implies a growing risk of environmental degradation when land quality has been deteriorated by over-farming and low humus application rates [27]. It is possible for Ghana's agriculture to grow through productivity increase. Agricultural growth is one of the main facets of Ghana's economic development and national food sufficiency policies [28]. Table 1 shows crops budget in US\$ for labour, capital and yield of mutant cassava-Tech Bankye and the conventional cassava varieties. Labour, land and capital are considered the three main inputs in agricultural production.

Labour input is measured as cost per "mandays" and it is a workforce involved in the agriculture cultivation that can be carried out by an adult male in an eight-hour work period. The data of workforce in agriculture which contributed to labour cost entails land clearing, planting, weeding, thrice for mutant and twice for other varieties, harvesting, bagging or carting to tractor trailer and transportation cost. Land input refers to the net cultivated area and is measured by net area cultivated. However, the comparison of this analysis was done on acre basis, thus land rent was considered as input in this analysis. Capital consists of all resources which contribute to cassava production on the farm and have been depreciated over two cropping seasons. Capital was measured in terms of net fixed capital in agriculture and data on capital cost entails variable inputs such as cassava sticks for propagation, cutlasses, hoes, sacks for loading cassava tubers and baskets to carry them from farm to bagging centre or trailer.

Farmers involved in this study cultivated the mutant cassava variety in addition to other traditional varieties such as Abasafita, Gblemoduade, Afisiafi, Nyamebekyere and Agric.. Table 1 shows the descriptive statistics of the crop budget of both mutant and other traditional varieties, respectively. The average cost of production per acre of the new mutant variety (\$264.00) is higher compared to that of the traditional variety (\$215.00) cultivated by the farmers. The reasons respondents gave are that the branches of the mutant variety cannot form canopies. This enhances weed growth adding additional cost for controlling weeds compared to the traditional varieties which after the second weeding, the branches form canopies and prevent weed growth till harvesting. Also, they could not get much leaves on the mutant branches to use as vegetables. There is no significant difference in capital cost between the mutant (\$3.00) and that of the traditional varieties (\$3.00), however, the mutants variety were higher in yields (up to 20 metric t/acre) and starch content than the traditional varieties whose highest yield was 15.55 metric tons.

The average net revenue of mutant variety per acre (\$119.28) was lower compared to the traditional varieties (\$131.27) making farmers hesitant to continue its cultivation. Eighty percent of the farmers complained difficulty in accessing market for the mutant variety since it could not replace the traditional

Table 1 Average crop budget per acre for mutant cassava compared to other cassava varieties.

\begin{tabular}{llll}
\hline & $N$ & Mutant cassava & Other varieties \\
\hline Acreage & 88 & 1 & 1 \\
Total cost of labour & 88 & $\$ 239.0$ & $\$ 190.00$ \\
Total cost of capital & 88 & $\$ 3.0$ & $\$ 3.00$ \\
Rent (land) & 88 & $\$ 20.0$ & $\$ 20.00$ \\
Total cost & 88 & $\$ 264.0$ & $\$ 215.00$ \\
Yield (metric ton) & 88 & 18.0 & 14.00 \\
Price per ton & 88 & $\$ 20.00$ & $\$ 11.00$ \\
Gross revenue & 88 & $\$ 378.0$ & $\$ 352.00$ \\
Net revenue & 88 & $\$ 119.28$ & $\$ 131.27$ \\
\hline
\end{tabular}


variety in terms of its texture for the local native "fufu" production and "ampesi". However, for industrial production of "gari" and starch, it was the best but fetched a lower price since the processing industries were not the mainstream. The problem of storing the fresh mutant cassava tubers for a longer period has led to leaving the roots in the ground until a market is located. The disadvantage is that large areas of land are occupied by mutant cassava tubers that is already mature and is not available for further cropping. Tubers left in the ground also risk damage by grasscutters, rats and moles as well as rot due to excessive rains.

Results for the Cobb-Douglas estimates are reported in Tables 2-7. The estimated agricultural production function for the gross revenue of mutant (GROM) cassava variety can be expressed in the following mathematical form as shown in Eqs. (5) and (6):

$$
\begin{aligned}
& \log _{e}(G R O M)=-3.47-0.01 \log _{e}(L) \\
& -3.18 \log _{e}(K)+20.92 \log _{e}(A)+\varepsilon
\end{aligned}
$$

From Eq. (5), we can see that the value of mutant cassava variety, Tech Bankye has output elasticities of labour, capital and cultivated acreage (land) as -0.01 , -3.18 and 20.92, respectively, compared to that of Eq. (6), the traditional varieties are 12.20 (labour), 0.39 (capital) and 136.24 of land. If $\alpha=-0.01$, and the labour input increases to about $1 \%$, then the gross value of mutant variety output decreases $0.01 \%$. Similarly, $\beta=-3.18$, and $\gamma=20.92$ can be interpreted in the same way. The analysis shows that land is more positively related to output holding labour and capital constant. The sum $(\alpha, \beta$ and $\gamma)$ gives information about the returns to scale, that is, response of output to a proportionate change in the input, in our case adding the three output elasticities we obtain 17.73 for the mutant varieties and 124.44 for that of the traditional ones which gives the value of the returns to scale

Table 2 Model summary ${ }^{\mathrm{b}}$.

\begin{tabular}{llllll}
\hline Model & $R$ & $R^{2}$ & Adjusted $R^{2}$ & Std. error of the estimate & Durbin-Watson \\
\hline 1 & $0.996^{\mathrm{a}}$ & 0.992 & 0.992 & $\$ 36.6100$ & 1.627 \\
\hline
\end{tabular}

${ }^{\mathrm{a} P r e d i c t o r s: ~(c o n s t a n t), ~ l a n d, ~ c a p i t a l ~ a n d ~ l a b o u r ; ~}{ }^{\mathrm{b}}$ dependent variable: GrossREVmut.

Table 3 ANOVA ${ }^{b}$.

\begin{tabular}{lllllll}
\hline Model & & Sum of squares & $d f$ & Mean square & $F$ & Sig. \\
\hline \multirow{2}{*}{1} & Regression & $1.479 \mathrm{E} 7$ & 3 & $4,929,771.157$ & $3,678.135$ & $0.000^{\mathrm{a}}$ \\
& Residual & $112,584.427$ & 84 & $1,340.291$ & & \\
& Total & $1.490 \mathrm{E} 7$ & 87 & & & \\
\hline
\end{tabular}

${ }^{\mathrm{a}}$ Predictors: (constant), land, capital and labour; ${ }^{\mathrm{b}}$ dependent variable: GrossREVmut.

\begin{tabular}{|c|c|c|c|c|c|c|}
\hline \multirow{2}{*}{ Model } & & \multicolumn{2}{|c|}{ Unstandardized coefficients } & \multirow{2}{*}{$\begin{array}{l}\text { Standardized coefficients } \\
\text { Beta }\end{array}$} & & \multirow{2}{*}{ Sig. } \\
\hline & & $B$ & Std. error & & & \\
\hline \multirow{4}{*}{1} & (Constant) & -3.470 & 9.248 & & -0.375 & 0.708 \\
\hline & Labour & -0.009 & 0.536 & -0.006 & -0.017 & 0.987 \\
\hline & Capital & -3.178 & 0.612 & -0.086 & -5.188 & 0.000 \\
\hline & Land & 20.920 & 6.347 & 1.062 & 3.296 & 0.001 \\
\hline
\end{tabular}

Table 4 Coefficients ${ }^{\mathrm{a}}$.

${ }^{\mathrm{a} D e p e n d e n t ~ v a r i a b l e: ~ G r o s s R E V m u t . ~}$

\begin{tabular}{|c|c|c|c|c|c|c|c|c|c|c|}
\hline \multirow{2}{*}{ Model } & \multirow{2}{*}{$R$} & \multirow{2}{*}{$R^{2}$} & \multirow{2}{*}{ Adjusted $R^{2}$} & \multirow{2}{*}{$\begin{array}{l}\text { Std. error of } \\
\text { the estimate }\end{array}$} & \multicolumn{5}{|c|}{ Change statistics } & \multirow{2}{*}{ - Durbin-Watson } \\
\hline & & & & & $R^{2}$ change & $F$ change & $d f_{1}$ & $d f_{2}$ & Sig. $F$ change & \\
\hline 1 & $0.971^{\mathrm{a}}$ & 0.944 & 0.942 & $\$ 40.41964$ & 0.944 & 469.861 & 3 & 84 & 0.000 & 2.011 \\
\hline
\end{tabular}

Table 5 Model summary ${ }^{b}$ for traditional varieties.

${ }^{\mathrm{a} P r e d i c t o r s: ~(c o n s t a n t), ~ l a n d, ~ c a p i t a l ~ a n d ~ l a b o u r ; ~}{ }^{b}$ dependent variable: GrosRevtradtn. 
Table 6 ANOVA $^{\mathrm{b}}$ for traditional varieties.

\begin{tabular}{lllllll}
\hline Model & & Sum of squares & $d f$ & Mean square & $F$ & Sig. \\
\hline \multirow{4}{*}{1} & Regression & $2,302,902.097$ & 3 & $767,634.032$ & 469.861 & $0.000^{\text {a }}$ \\
& Residual & $137,234.800$ & 84 & $1,633.748$ & & \\
& Total & $2,440,136.898$ & 87 & & & \\
\hline
\end{tabular}

aredictors: (constant), land, capital and labour; bdependent variable: GrosRevtradtn.

Table 7 Coefficients ${ }^{\mathrm{a}}$ for traditional varieties.

\begin{tabular}{|c|c|c|c|c|c|c|}
\hline \multirow{2}{*}{ Model } & & \multicolumn{2}{|c|}{ Unstandardized coefficients } & \multicolumn{2}{|l|}{ Standardized coefficients } & \multirow{2}{*}{ Sig. } \\
\hline & & $B$ & Std. error & Beta & & \\
\hline \multirow{4}{*}{1} & (Constant) & -85.869 & 37.070 & & -2.316 & 0.023 \\
\hline & Labour & -12.198 & 2.318 & -7.200 & -5.263 & 0.000 \\
\hline & Capital & 0.394 & 0.560 & 0.023 & 0.704 & 0.484 \\
\hline & Land & 136.244 & 22.831 & 8.148 & 5.967 & 0.000 \\
\hline
\end{tabular}

${ }^{\mathrm{a} D e p e n d e n t ~ v a r i a b l e: ~ G r o s R e v t r a d t n . ~}$

parameter. As we can see the sums are greater than 1 , thus there are increasing returns to scale.

$$
\begin{aligned}
& \log _{e}(G R O V)=-85.87-12.20 \log _{e}(L) \\
& +0.39 \log _{e}(K)+136.24 \log _{e}(A)+\varepsilon
\end{aligned}
$$

The constant value shows that the opportunity cost of forgoing an acre of the traditional varieties to cultivating the mutant variety is very expensive (US\$85.87). Though the gross revenue of the mutant variety is significantly high, their cost of production is high making the net revenue of the traditional cassava varieties are higher than that of mutant varieties. Our recent study revealed that $75 \%$ of the respondents has stop cultivating the mutant variety with reasons being inadequate markets leading to lower prices. From a purely statistical viewpoint, the estimated regression line fits the data quite well for both mutant variety $\left(R^{2}\right.$ $=99.2)$ and that of the traditional varieties $\left(R^{2}=94.4\right)$. The $R^{2}$ value of 0.992 means that $99.2 \%$ of the variation in the (logarithmic of) gross value of mutant cassava output is explained by the (logarithmic of) land, labour and capital. For adjusted $R^{2}$, the relation is $99.2 \%$. This shows the statistical dependence of the (logarithmic of) gross value of mutant cassava output on the (logarithmic of) labour, land and capital. $\alpha, \beta$, and $\gamma$ are statistically significant at the $5 \%$ level.

In summary, the analysis shows that land is the main factor of cassava productivity and a less return to scale variety would exacerbate the choice of adoption compared to already cultivated crops considered in Ghana.

\section{Conclusions}

Results show that farmers cultivate the mutant variety in addition to other traditional varieties to averse risking in marketing and income generation since the mutant could not completely replace the traditional varieties in attributes. The traditional varieties cultivation is less labour intensive than the mutant variety. Most farmers are desisting from Tech Bankye production due to its high production cost as a result of vigorous weed growth since the variety cannot form canopy. Mutant cassavas roots also have short neck and must be harvested and handled with extreme care to avoid bruises especially to the neck region to prevent a rapid deterioration after harvesting. However, this is uncommon with the traditional cassava varieties. Rapid post-harvest deterioration of cassava roots places serious constraints on their distribution and use, especially where there are delays in marketing, and on the holding of buffer stocks for large-scale processing. As a result, the selection of a market for which production is intended is influenced by its location and the time scale for delivery rather than its simple proximity to the production area. A less return to scale technology such as the mutant cassava varieties would exacerbate the choice of 
innovation adoption in Ghana. However, for industrial raw material, the mutant variety is the best because of its high starch content.

Similar study will be done for the cocoa production sectors of Ghana. According to the Cocoa Research Institute of Ghana (CRIG) at Tafo, no count of swollen shoot virus has been made so far as far as mutant cocoa is concerned compared to non-mutant ones for more than two decades. The study will be conducted to find out and to confirm this and other impact of the mutant cocoa varieties.

\section{Acknowledgments}

The authors would like to take this opportunity to express very sincere thanks and appreciation to Cesil Osei of Root and Tuber Improvement and Marketing Programme (RTIMP). Also, the authors' sincere thanks go to Dr. Richard Akromah, Dr. E. Asare, Dr. J. A. Sarkodie, Dr. L. K. Amekudzi, Dr. K. Preko and Mr. Thomas Adjei all of KNUST. The authors' gratitude also go to the former Director of BNARI Prof. Josephine Nketsia-Tabiri and Kojo Asempa for their support. In the latter category, the authors are particularly grateful to their parents and family members for their love and support.

\section{References}

[1] K.E. Banson, N.C. Nguyen, O.J.H. Bosch, T.V. Nguyen, A Systems Thinking Approach to Address the Complexity of Agribusiness for Sustainable Development in Africa: A Case Study in Ghana, Systems Research and Behavioral Science, 2014.

[2] R. Graham, D. Senadhira, S. Beebe, C. Iglesias, I. Monasterio, Breeding for micronutrient density in edible portions of staple food crops: Conventional approaches, Field Crops Research 60 (1) (1999) 57-80.

[3] P. Hill, The Migrant Cocoa-Farmers of Southern Ghana: A Study in Rural Capitalism, LIT Verlag Münster, 1997.

[4] S. Kolavalli, M. Vigneri, Cocoa in Ghana: Shaping the success of an economy, in: Yes, Africa Can: Success Stories from a Dynamic Continent, World Bank Publications, Washington DC, 2011, pp. 201-218.

[5] G. Otim-Nape, A. Bua, Y. Baguma, Accelerating the transfer of improved production technologies: Controlling African cassava mosaic virus disease epidemics in
Uganda, African Crop Science Journal 2 (4) (1994) 479-495.

[6] A. Ntiamoah, G. Afrane, Environmental impacts of cocoa production and processing in Ghana: Life cycle assessment approach, Journal of Cleaner Production 16 (2008) 1735-1740.

[7] H. Dzahini-Obiatey, O. Domfeh, F. Amoah, Over seventy years of a viral disease of cocoa in Ghana: From researchers' perspective, African Journal of Agricultural Research 5 (7) (2010) 476-485.

[8] J.A. Dixon, D.P. Gibbon, A. Gulliver, Farming Systems and Poverty: Improving Farmers' Livelihoods in a Changing World, Food \& Agriculture Org., 2001.

[9] A. Pandey, C.R. Soccol, P. Nigam, V.T. Soccol, L.P. Vandenberghe, R. Mohan, Biotechnological potential of agro-industrial residues, II-Cassava bagasse, Bioresource Technology 74 (1) (2000) 81-87.

[10] F.I. Nweke, New challenges in the cassava transformation in Nigeria and Ghana, EPTD Discussion Paper, International Food Policy Research Institute, Washington DC, 2004, p. 118.

[11] J. Legg, C. Fauquet, Cassava mosaic geminiviruses in Africa, Plant Molecular Biology 56 (4) (2004) 585-599.

[12] H. Dzahini-Obiatey, G.A. Ameyaw, L. Ollennu, Control of cocoa swollen shoot disease by eradicating infected trees in Ghana: A survey of treated and replanted areas, Crop Protection 25 (7) (2006) 647-652.

[13] W. Stevens, Swollen shoot and die-back-A new disease of cocoa, Gold Coast Farmer 5 (1936) 144.

[14] T. Takane, Smallholders and nontraditional exports under economic liberalization: The case of pineapples in Ghana, African Study Monographs 25 (1) (2004) 29-43.

[15] L. Whitfield, Developing Technological Capabilities in Agro-industry: Ghana’s Experience with Fresh Pineapple Exports in Comparative Perspective, Econstor, Germany, 2010.

[16] G. Owusu, The cocoa swollen shoot disease problem in Ghana, in: R.T. Plumb, J.M. Thresh (Eds.), Plant Virus Epidemiology, Blackwell Scientific, Oxford, 1983, pp. 73-83.

[17] Y.A. Ampomah, G. Owusu, S. Sackey, B. Padi, A. Abdul-Karimu, Use of gamma rays to induce mutants resistant to cocoa swollen shoot disease in Theobroma cacao L., Plant Breeding 115 (1) (1996) 74-76.

[18] A. Hanna, E. Judenko, W. Heatherington, Systemic insecticides for the control of insects transmitting swollen-shoot virus disease of cacao in the Gold Coast, Bulletin of Entomological Research 46 (3) (1955) 669-710.

[19] J.M. Thresh, G. Owusu, The control of cocoa swollen shoot disease in Ghana: An evaluation of eradication procedures, Crop Protection 5 (1) (1986) 41-52. 
[20] F. Novak, H. Brunner, Plant breeding: Induced mutation technology for crop improvement, IAEC Bulletin 4 (1992) 25-33.

[21] C. Broertjes, Application of mutation breeding methods in the improvement of vegetatively propagated crops, in: Development in Crop Science, Elsevier, Amsterdam, 2012.

[22] B. Ahloowalia, M. Maluszynski, K. Nichterlein, Global impact of mutation-derived varieties, Euphytica 135 (2) (2004) 187-204.

[23] K. Banson, K. Danso, Improving the size and market value of an underutilised yam (Dioscorea esculenta) in Ghana: Implications for crop breeding and production choices, Journal of Life Sciences 7 (7) (2013) 732-741.

[24] G. Zaman, Z. Goschin, Technical change as exogenous or endogenous factor in the production function models, empirical evidence from Romania, Journal for Economic Forecasting 2 (2010) 29-45.

[25] A.F.D. Avila, T.R. Quirino, E. Contini, E.L.R. Filho, R.
Evenson, V. Santaniello, et al., Social and economic impact ex-ante evaluation of Embrapa's biotechnology research products, in: Economic and Social Issues in Agricultural Biotechnology, CABI Publishing, New York, 2002, pp. 287-308.

[26] X. Diao, Economic Importance of Agriculture for Sustainable Development and Poverty Reduction: Findings from a Case Study of Ghana [Online], 2010, http://www.oecd.org/tad/agricultural-policies/46341169.p df (accessed Apr. 14, 2014).

[27] S.M. Islam, Economic growth and social welfare: An aggregate approah, Contributions to Economic Analysis 262 (2004) 47-72.

[28] K.E. Banson, N.C. Nguyen, O.J.H. Bosch, Systemic intervention to tackle the constraints and challenges facing stakeholders and the performance of the agricultural sector in Ghana, in: 9th Annual System of Systems Engineering Conference, Adelaide, 2014. 